\title{
WORKLOAD AND ENERGY EXPENDITURE DURING WHEELCHAIR PROPELLING ${ }^{1}$
}

\author{
By Hans Stoboy ${ }^{2}$, Bryan Wilson Rich ${ }^{3}$ and MAthew LeE ${ }^{4}$ \\ New York University Medical Centre, Goldwater Memorial Hospital \\ Rehabilitation Medicine Service
}

VERY little information on the performance of wheelchair driving in terms of physical workload in Watts or of energy expenditure is available. Gordon (1952, I958) studied the energy cost during regular indoor wheelchair propelling and reported an expenditure of $2 \cdot 4 \mathrm{kcal}$. $/ \mathrm{min}$. at a speed of $\mathrm{I} \cdot 2 \mathrm{miles} / \mathrm{h}$. $(\mathrm{km}$. I $\cdot 9)$.

This average value unfortunately doesn't make reference to usual standards as body weight or body surface area of the subjects and therefore doesn't permit generalisation.

In preliminary studies Lee and Mannon (1967) tried to find the differences in energy expenditure during wheelchair driving with two differently constructed wheelchairs. The energy expenditure was significantly lower while driving a newly designed geared wheelchair than while propelling the chair in the conventional manner. It couldn't be shown exactly whether this difference was due to better efficiency or lower workload or the newly constructed chair or to different velocities. For the continuation of this study we tried to find the workload of wheelchair driving in physical units (watts or $\mathrm{kpm}$./sec.). Pilot studies showed that the workload in free indoor wheelchair driving was between $t \frac{1}{2}$ o I watt $/ \mathrm{kg}$. of body weight.

As reported by Åstrand (1965), Mellerowicz (I96I), etc., heartrate, $\mathrm{O}_{2}$ uptake and other cardio-pulmonary parameters are very constant in the same individual at the same workload. Therefore we compared cardio-pulmonary parameters measured during wheelchair propelling with those measured during ergometric performance with the aim to evaluate the physical load in watts or $\mathrm{kg}$. $/ \mathrm{sec}$.

\section{METHODS AND MATERIAL}

The experiments were carried out with is healthy and completely untrained male subjects between 18 and 30 years of age.

Three different tests have been employed:

1 This study was partially supported by Grant No. CD 0003 I-Io from the U.S. Department of Health, Education and Welfare, and supported in part by the Social and Rehabilitation Service, Department of Health, Education and Welfare, under the designation of New York University as a rehabilitation research and training centre.

Present addresses:

${ }^{2}$ Orthopädische Klinik und Poliklinik der Freien Universität Berlin im Oskar-HeleneHeim, I Berlin 33, Clayallee 229/233.

3 I65 East 32nd Street, New York, N.Y. Ioor6.

4 New York University Medical Centre, Goldwater Memorial Hospital, Welfare Island, New York, N.Y. IOOI7. 
I. An ergometer was adapted so that the subject sitting in a wheelchair with fixed brakes could handcrank it (fig. I).

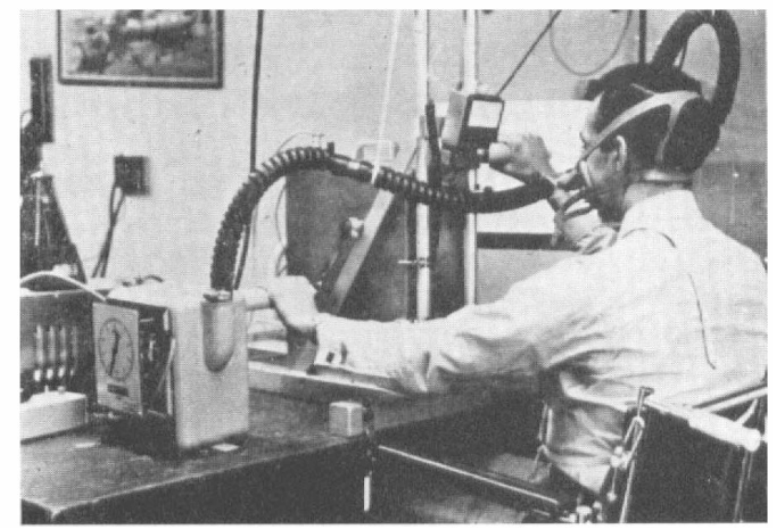

FIG. I

Handcranking of a wheelchair-adapted ergometer.

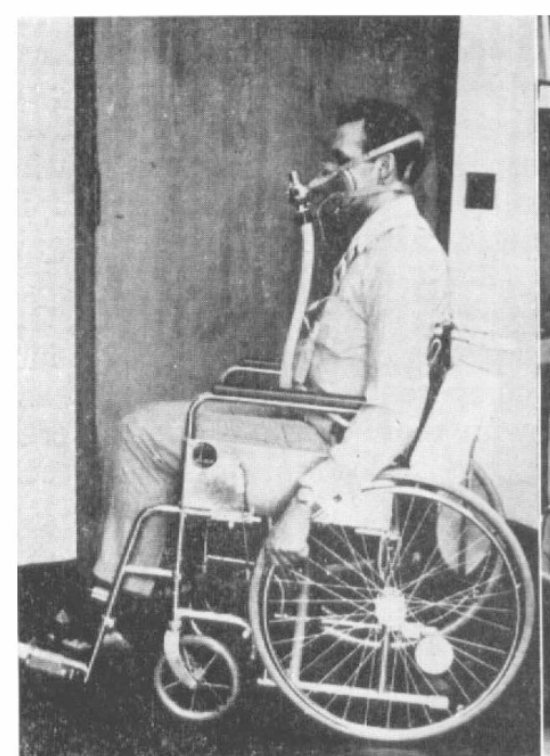

FIG. 2

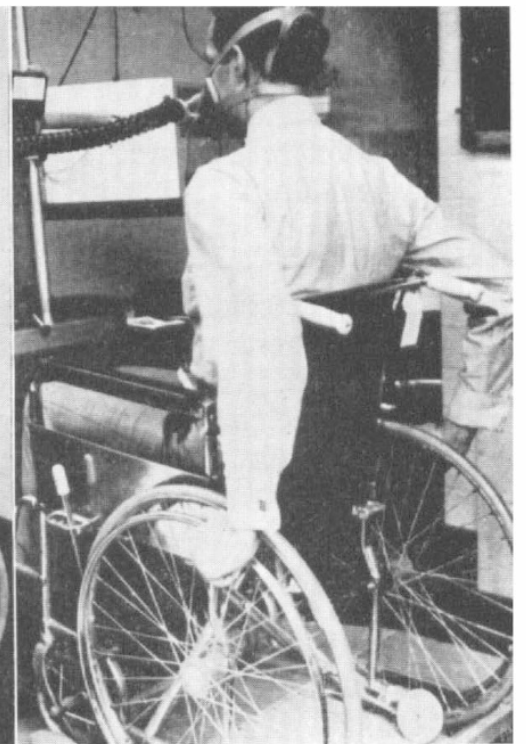

FIG. 3

Fig. 2.-Free wheelchair driving and sampling of expired air.

Fig. 3.-Paced wheelchair driving on the wheelchair platform.

He was asked to perform at standard workloads of $\frac{1}{2}$ watt $/ \mathrm{kg}$. body weight and at I watt $/ \mathrm{kg}$. body weight for 5 minutes each. During a preceeding period of 10 minutes of rest, the performance and a recovery period of ro minutes the following parameters have been recorded and/or calculated simultaneously: 
(a) The heart rate and the percentage of increase over initial heart rate was calculated from an ECG record picked up by one chest lead and telemetered to the recording system.

(b) The volumes of respiration were recorded by means of an potentiometerfitted gas meter in the inspiratory part of an open system.

(c) Expiratory $\mathrm{O}_{2}$ and $\mathrm{CO}_{2}$ content were measured continuously by means of a paramagnetic and an infrared gas analyser. From these values $\mathrm{O}_{2}$ uptake and $\mathrm{CO}_{2}$ elimination could be calculated.

2. In a second procedure the subjects were asked to drive a conventional wheelchair 5 to 6 minutes at a convenient speed. During the last 2 minutes the volume of respiration was measured with the Korfryani-Müller-Spirometer and samples of expired air were taken for $\mathrm{O}_{2}$ and $\mathrm{CO}_{2}$ analyses. The heart rate was recorded by telemetry (fig. 2).

3. The third procedure consisted in 5 minutes' wheelchair driving on a specially constructed platform (Hans Krobath, Abilities Incorporated; fig. 3). The platform was equipped with rollers not allowing the subject to give ballistic impulses to the wheelchair. The subject had to move the wheels 18 times/minute with full range. During this performance the above-mentioned parameters could be measured continuously.

\section{RESULTS}

During ergometric performance with $\frac{1}{2}$ watt $/ \mathrm{kg}$. the heart rate increased from $77 \cdot \mathrm{I}(s=8 \cdot \mathrm{I})$ to $90 \cdot 5(+\mathrm{I} 8$ per cent.; $s=7 \cdot 7)$ reaching a steady state. With I watt $/ \mathrm{kg}$. a steady state was not obtained definitely and the end-value was I I I ( 44.5 per cent.; $s=$ IO. I) (fig. 4$)$.

The same conduct could be observed in minute volume of respiration which in the first part of performance was enhanced from $8.9(s=2 \cdot 02)$ to I 5.21 . $(s=2.64)$ and increased in the second part up to 281 . $(s=6 \cdot 17)$.

The $\mathrm{O}_{2}$ uptake increased in the first part from $290 \mathrm{ml} . / \mathrm{min} .(s=42 \cdot 0)$ to $620 \mathrm{ml} . / \mathrm{min}$. ( $(s=\mathrm{IOI} \cdot 9)$ and reached II $30 \mathrm{ml}$. $(s=165 \cdot 7)$ during the second part (fig. 4).

The RQ showed starting from the rest value $0.85(s=0.05)$ the typical dip at the beginning of performance and rose first to $0.89(s=0.04)$ and increased in the second part up to $0.99(s=0.04)$. After performance the RQ exceeded $\mathrm{I} \cdot 0$ as usual with a peak value in the second minute $(I \cdot I ; s=0.08)$. The last value in the recovery period was $0.84(s=0.05)$ (fig. 4$)$.

The metabolic cost was at rest I.39 kcal. $/ \mathrm{min}$.; $s=0.2 \mathrm{I}\left(0.73 / \mathrm{m} .^{2}\right.$ body surface area; $s=0 . \mathrm{I})$ and was enhanced to $3 . \mathrm{I}(s=0.5)$ and $5.7 \mathrm{kcal} . / \mathrm{min}$. $(s=0.8)$ respectively $\left(\mathrm{I} \cdot 54 ; s=0.2 \mathrm{I}\right.$ and $3.0 \mathrm{kcal} . / \mathrm{m}^{2}$. body surface area; $\left.s=0.36\right)$. So the net values for ergometric performance were $1 \cdot 7$ and $4 \cdot 3 \mathrm{kcal} . / \mathrm{min}$. respectively.

During free wheelchair driving the values increased in average as follows:

Heart rate: 97. I ( +23 per cent. $)$

Minute volume of respiration:

$\mathrm{O}_{2}$ uptake:

RQ:

I $6.3 \mathrm{l} . \mathrm{min}$.

$658 \mathrm{ml} . / \mathrm{min}$.

0.92 
Energy expenditure:

Energy expenditure/bsa:
$3 \cdot 15 \mathrm{kcal} . / \mathrm{min}$.

$\mathrm{I} \cdot 6 \mathrm{I} \mathrm{kcal} . / \mathrm{min} . \cdot \mathrm{m}^{2}$

The net values were $\mathrm{I} \cdot 8 \mathrm{kcal} . / \mathrm{min}$. and $0.89 \mathrm{kcal} . / \mathrm{m} .^{2} \cdot \mathrm{min}$.

During paced ergometric performance at the platform the average range for one movement was 0.38 metres. So the total distance in 5 minutes was 52 metres or $0.62 \mathrm{~km}$. per hour.

The heart rate increased from the rest value of $78 / \mathrm{min}$. $(s=8 \cdot 4)$ to $99 / \mathrm{min}$. $(s=$ II 5 I $)$ during performance ( +29 per cent.) (fig. 5).

The minute volume of ventilation was enlarged from $8 \cdot 21 .(s=2 \cdot 2)$ to $17 \cdot 31$. $(s=4 \cdot 0)$, the $\mathrm{O}_{2}$ consumption from $30 \mathrm{I}\left(s=49^{\circ} 0\right)$ to $733 \mathrm{ml} . / \mathrm{min}$. $\left(s=149^{\cdot 6}\right)$. So the calculated RQ was 0.91 ( $(s=0.08)$ (fig. 5).

The gross energy expenditure amounted to $3.6 \mathrm{kcal} . / \mathrm{min} . \quad(s=0.75)$ ( $\left.1 \cdot 9 \mathrm{kcal} . / \mathrm{min} . \cdot \mathrm{m} .{ }^{2} ; s=0 \cdot 38\right)$.

The net energy expenditure was in average $2 \cdot 2 \mathrm{kcal} . / \mathrm{min}$. ( $\mathrm{I} \cdot \mathrm{I} \mathrm{kcal} . / \mathrm{m} .{ }^{2} \cdot \mathrm{min}$.).

\section{DISCUSSION}

Because of the unusual ergometric positioning (normally: cranking in a standing position, bicycling in a sitting or supine position) the obtained values were compared with normal standards at the same workloads.

Heart rate, minute volume of respiration and $\mathrm{O}_{2}$ uptake fitted well in the normal pattern and were situated in the lower part of the $2 \delta$ range (Mellerowicz, 196I). This is probably due to the fact that the muscle mass employed in this performance is less than during hand cranking in a standing position. But the values are exactly comparable with those during bicycling in the supine position with those during bicycling in the supine position at the same workload. This finding gives enough evidence to correlate the applied ergometric procedure with standard methods.

Only the RQ is slightly larger than in standard performances. This is probably due to a collective of completely sedentary subjects. The net metabolic cost can be compared with walking on a plain ground with a speed of $2 \cdot 0$ or $5 \cdot 3 \mathrm{~km}$. $/ \mathrm{h}$. respectively.

During free wheelchair driving $\mathrm{O}_{2}$ consumption and energy expenditure varied up to \pm 28 per cent. depending on body weight $(\bar{X}=75 \cdot 2 \mathrm{kp}$; $s \pm 9 \cdot 96)$ and velocity $(\bar{X}=3.0 \mathrm{~km}$. $/ \mathrm{h} . ; s \pm 0.44)$. This large range could be diminished by calculating the $\mathrm{O}_{2}$ uptake and the metabolic cost per unit of velocity $(\mathrm{km} . / \mathrm{h}$.) and $\mathrm{kg}$. body weight. Then the values turned out as $3.0 \mathrm{I} \mathrm{ml.} \mathrm{O}_{2} / \mathrm{v} \cdot \cdot \mathrm{kg}$.; $s-0.2 \mathrm{I}$ and I5.I gcal./v. $\cdot \mathrm{kg}$.; $s-\mathrm{I} \cdot 03$. The net energy consumption was in average $\mathrm{I} \cdot 8 \mathrm{kcal} \cdot /$ min. and $0.89 \mathrm{kcal} . / \mathrm{min} . \cdot \mathrm{m}^{2}{ }^{2}$ which equals the metabolic cost of walking on plain ground with a velocity of $2 \mathrm{~km}$. $/ \mathrm{h}$.

During performance on the wheelchair platform $\mathrm{O}_{2}$ consumption and energy expenditure showed a much less interindividual variation than in free wheelchair driving with a standard deviation of less than 9 per cent. The net energetic cost of $2 \cdot 2 \mathrm{kcal}$. $/ \mathrm{min}$. and I $\cdot \mathrm{I} \mathrm{kcal} . / \mathrm{m} .^{2} \cdot$ min. equals walking with a velocity of $3 \mathrm{~km} . / \mathrm{h}$.

The distance which was covered in 5 minutes in the platform procedure was significantly less $(52 \mathrm{~m}$.) than in 5 minutes of free wheelchair propelling $(250 \mathrm{~m}$.). However, the energy expenditure in the platform investigations is about 20 per cent. larger than in free wheelchair driving. This reciprocal behaviour can be 

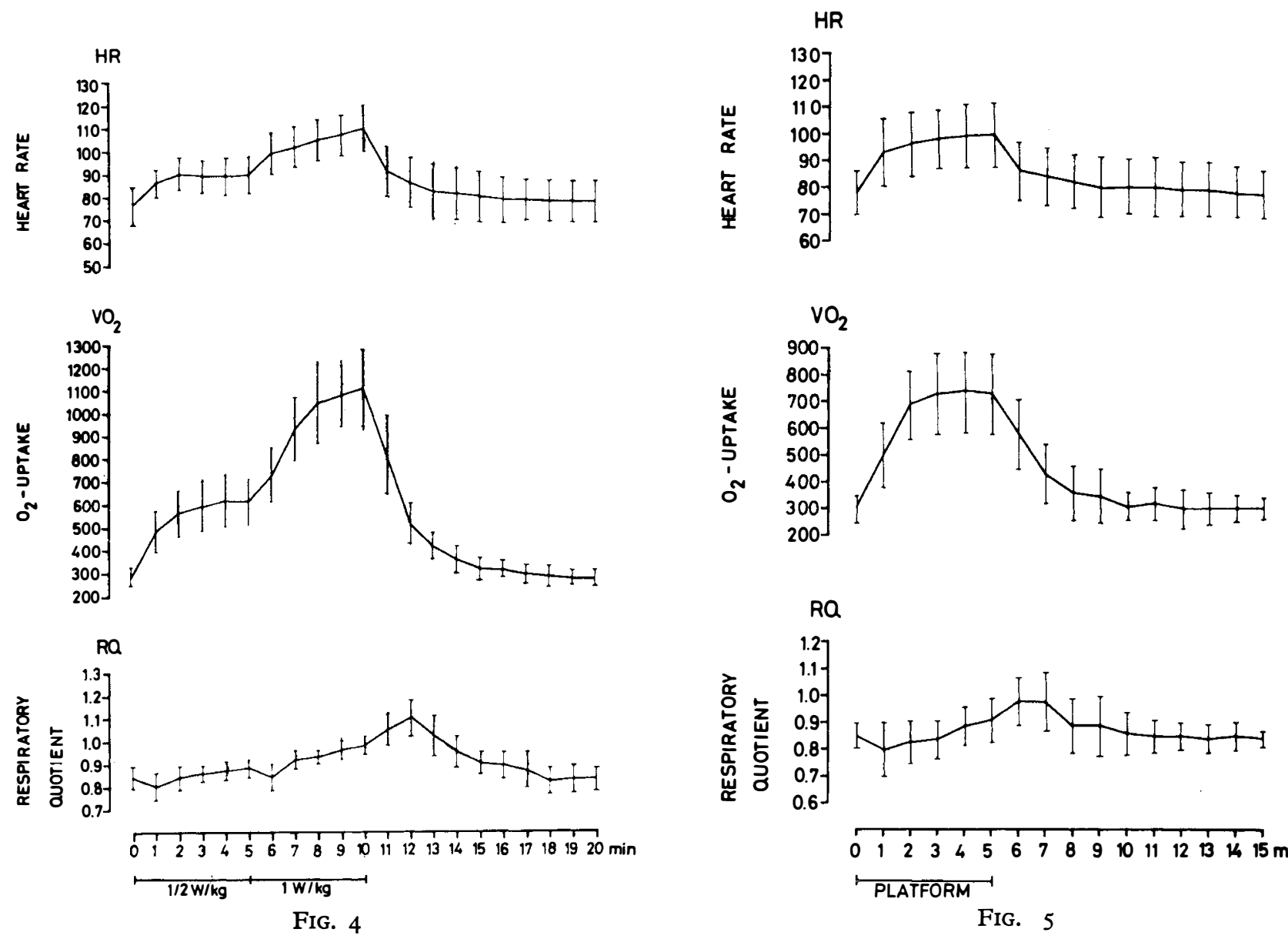

Heart rate, $\mathrm{O}_{2}$ uptake and RQ during handcranking with $\frac{1}{2}$ and I watt $/ \mathrm{kg}$. body weight. Brackets indicate standard deviation.

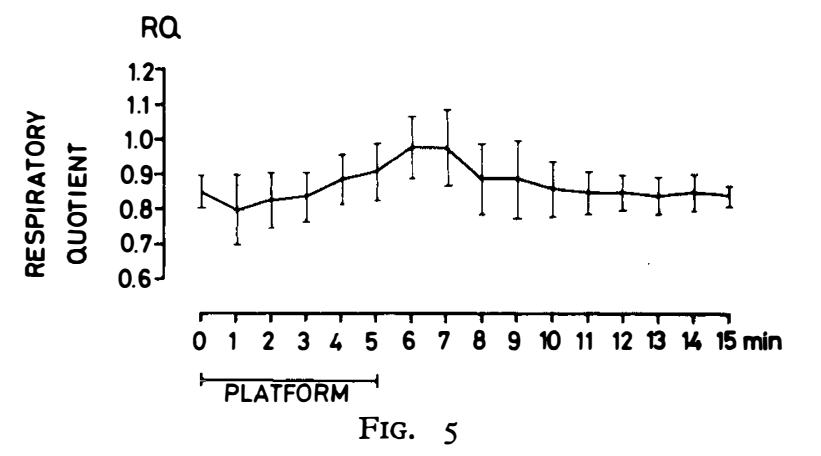

Heart rate, $\mathrm{O}_{2}$ uptake and RQ during paced wheelchair propelling on the platform. Brackets indicate standard deviation. 
explained by the fact that there is no possibility of free wheelchair rolling during platform performance so that for the same distance as in free wheelchair propelling an extremely larger power has to be raised.

The calculation for the physical exertion was done in the following way:

The data collected in the second and third procedure were projected on the graph of ergometric performance and plotted along the $x$ axis to estimate the physical workload in watts.

The value of the physical workload varied depending on the parameter which was used for ergometric performance graph, i.e., heart rate, minute volume of respiration, $\mathrm{O}_{2}$ consumption or $\mathrm{RQ}$ (fig. 6).

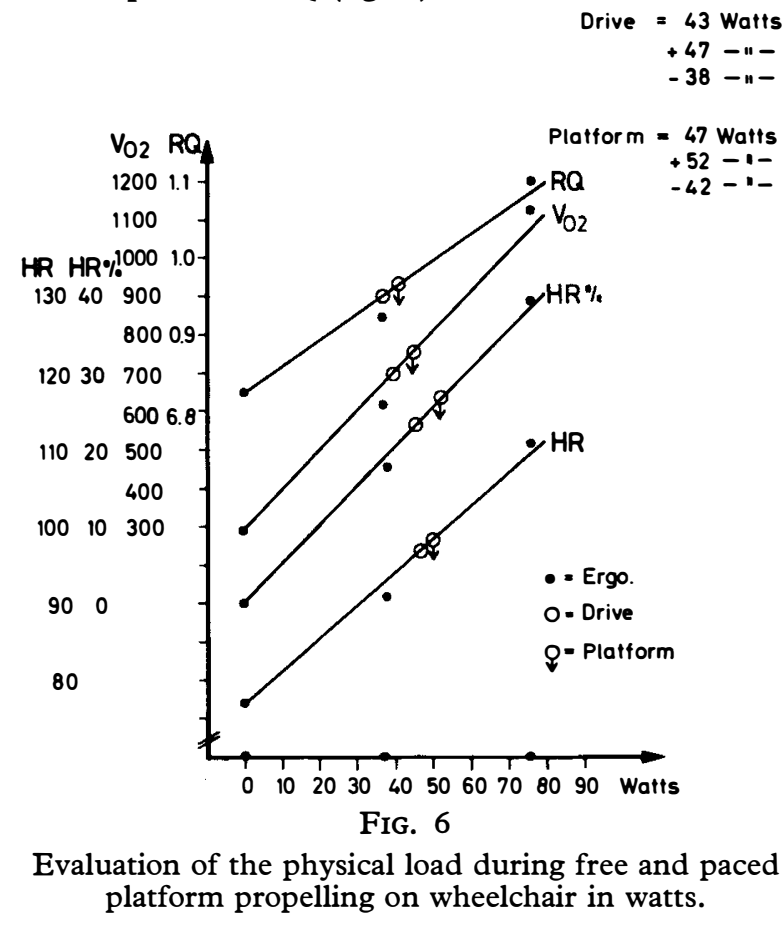

In average the physical workload for free wheelchair driving could be calculated as 43 watts within a range of \pm 5 watts.

The average value for the platform experiments was slightly larger (47 watts) but could be determined with the same accuracy. Voigt (I968): Voigt, Berendes and Hildebrandt (1968) tried to calculate the physical workload in propelling wheelchairs on a specially constructed treadmill with different velocities. They determined the physical workload by an equibilation between the resistance of the rollers and counterweights as it is similarily done in calibrating ergometers with the Prony method. From this measurement they concluded that even at relatively high speeds so as $3.0 \mathrm{~km}$./h. the workload was less than ro watts.

However, their values for heart rate, $\mathrm{O}_{2}$ uptake and minute volume of respiration (124.4/min., $649 \mathrm{ml} . / \mathrm{min} ., 18.6 \mathrm{l} / \mathrm{min}$.) fit well in the range between 30 and 50 watts of standard ergometric investigations or are even larger. In our opinion the evaluation of the physical workload by means of measured cardiopulmonary 
parameters is more efficient in judging the fitness of wheelchair-propelling subjects because this method represents exertion and fatigue of the subjects. The same procedures were also performed by 15 paraplegic or high above the knee amputies but the data are in progressing. We hope that with this method, after further investigations, it will be possible to calculate the physical workload of wheelchair propelling in a sufficient range for paraplegic or high above the knee amputies and to judge the ability for wheelchair driving by the depicted ergometric method.

\section{SUMMARY}

In this investigation it was tried to evaluate the workload of wheelchair driving in physical units, i.e. watts or meter $\mathrm{kg}$./ $\mathrm{sec}$. For this reason an ergometer was adapted so that subjects sitting in wheelchairs with fixed brakes, could hand frank it. They were asked to perform at a standard workload of $\frac{1}{2} \mathrm{watt} / \mathrm{kg}$. body weight and at I watt $/ \mathrm{kg}$. body weight for 5 minutes each. During this time heart rate, $\mathrm{CO}_{2}$ elimination, $\mathrm{O}_{2}$ uptake, minute volume of respiration and the $\mathrm{RQ}$ were continuously recorded or calculated. In a second procedure these subjects were asked to drive a conventional wheelchair 5 to 6 minutes at a convenient speed. During the last 2 minutes the $\mathrm{V}$ was measured with the Korfryani-Müller spirometer and samples of expired air were taken for $\mathrm{O}_{2}$ and $\mathrm{CO}_{2}$ analysis. The heart rate was recorded by telemetry. In a third procedure the subjects drove their wheelchairs for 5 minutes on platforms equipped with rollers so that the above mentioned parameters could be measured continuously. The data collected in the second and third parts of the experiment were projected on the graph of performance of ergometric experiments, and plotted along the $\mathrm{X}$-axis to estimate the workload in watts. By this method it was possible to calculate the physical workload of wheelchair driving within a range of approximately \pm 5 watts.

\section{RÉSUMÉ}

Des études ont été effectuées en ce qui concerne le travail et le besoin énergétique pour la propulsion d'une chaise roulante grâce à un ergomètre adapté. Dans la première expérience, sur l'ergomètre, un travail spécifique a été demandé. Dans la deuxième procédure, on a demandé aux paraplégiques de pousser leurs chaises à une certaine vitesse, pendant 5 ou 6 minutes. Au cours de la troisième procédure, les sujets ont poussé leurs chaises, pendant 5 minutes, sur des plate-formes spéciales équipées de roulettes. Différents paramètres ont été mesurés de façon continue. Grâce à ces méthodes, il a été possible de calculer le travail physique de conduite d'une chaise roulante avec une erreur de plus ou moins 5 watts.

\section{ZUSAMMENFASSUNG}

In dieser Untersuchung wurde versucht, die Arbeitsleistung von Rollstuhlfahreren in physicalischen Einheiten, i.e. Watts und Meter/Kg/Sek. zu bestimmen. Für diesen Zweck wurde ein Ergometer so adaptiert, dass das Individuum, im Rollstuhl mit fixierten Bremsen sitzend, frei mit Handbertrieb arbeiten kommte. Die Versuchskandidaten wurden beauftragt, eine Standard Arbeitsleistung von: 2 Watt/Kg Körpergewicht und I Watt/Kg Körpergewicht für je 5 Minuten auszuführen. Während dieser Zeit wurden Herzfrequenz, $\mathrm{CO}_{2}$ und $\mathrm{O}_{2}$ Austausch, Minutenvolumen der Atmung und $\mathrm{R} \mathrm{Q}$ kontinuierlich bestimmt oder kalkuliert. In einem zweiten Versuch hatten die Individuen einen konventionellen Rollstuhl für 5-6 Minuten bei einer bestimmten Schnelligkeit zu fahren. Während der letzten 2 Minuten wurde V mit dem Korfryani-Müller Spirometer gemessen und Proben 
von ausgeatmeter Luft wurden für $\mathrm{O}_{2}$ und $\mathrm{CO}_{2}$ Analyse genommen. Die Herzfrequenz wurde bei Telemetrie gemessen. In einem dritten Experiment hatten die Individuen ihren Rollstuhl für 5 Minuten auf einer Plattform zu fahren, die mit Rollen versehen war, so dass die Parameter kontinuierlich gemessen werden konnten.

Die Daten, die sich aus dem 2. und 3. Experiment ergaben, wurden graphisch projiziert und die Arbeitsleistung in Watts bestimmt.

Acknowledgment. We want to thank M. Smodlaka and E. Griffin for technical assistance and F. Trainor, Ph.D., for organisatory help.

\section{REFERENCES}

Åstrand, P.-O. (1965). Internationales Seminar für Ergometrie, pp. 5-I4. Berlin: Institut fñr Leistungsmedizin.

Gordon, E. E. (1952). Arch. Physical Med. 33, 4, $201-209$.

Gordon, E. E. (1958). A.M.A. Arch. Int. Med. I0I (4), 702-712.

LeE, M. \& M. ManNon (1967). Staff Evaluation Conference-Goldwater Memorial Hospital, Rehabilitation Medicine New York University, Medical Center, July.

Mellerowicz, H. (I96I). Ergometrie. München-Berlin: Urban und Schwarzenberg.

VoIGT, E.-D. (I968). Diskussionsbeitrag zu: Rehabilitation von Patienten mit orthopädischen Erkrankungen und posttraumatischen Schäden. In: Io fahre Rehabilitation als Schlüssel zum Dauerarbeitsplatz, pp. 259-265. Stuttgart: Gentner-Verlag.

Voigt, E.-D., Berendes, B. \& Hilderbrand, G. (1968). Arbeitsmedizin, Sozialmedizin Arbeitshygiene, 3, I35-I 38 . 